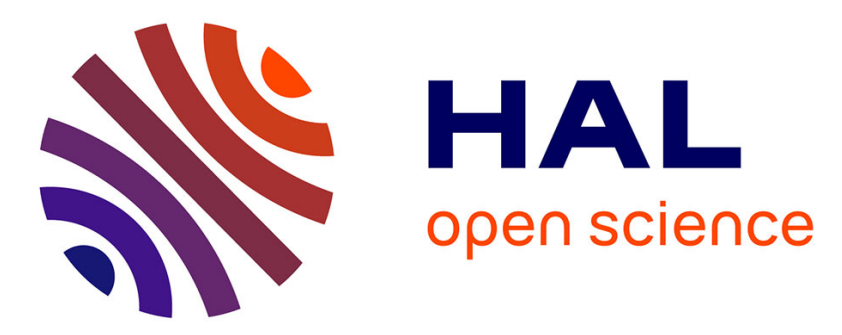

\title{
Synthesis, characterisation and catalytic use of iron porphyrin amino ester conjugates
}

\author{
D.M. Carminati, D. Intrieri, S. Le Gac, T. Roisnel, B. Boitrel, L. Toma, L. \\ Legnani, E. Gallo
}

\section{- To cite this version:}

D.M. Carminati, D. Intrieri, S. Le Gac, T. Roisnel, B. Boitrel, et al.. Synthesis, characterisation and catalytic use of iron porphyrin amino ester conjugates. New Journal of Chemistry, 2017, 41 (13), pp.5950-5959. 10.1039/c7nj01189j . hal-01581220

HAL Id: hal-01581220

https://hal-univ-rennes1.archives-ouvertes.fr/hal-01581220

Submitted on 4 Sep 2017

HAL is a multi-disciplinary open access archive for the deposit and dissemination of scientific research documents, whether they are published or not. The documents may come from teaching and research institutions in France or abroad, or from public or private research centers.
L'archive ouverte pluridisciplinaire HAL, est destinée au dépôt et à la diffusion de documents scientifiques de niveau recherche, publiés ou non, émanant des établissements d'enseignement et de recherche français ou étrangers, des laboratoires publics ou privés. 


\section{Synthesis, Characterisation and Catalytic Use of Iron Porphyrin Amino Ester Conjugates}

Daniela M. Carminati, ${ }^{a}$ Daniela Intrieri, ${ }^{\text {a }}$ Stéphane Le Gac, ${ }^{b}$ Thierry Roisnel, ${ }^{\mathrm{b}}$ Bernard Boitrel, ${ }^{\mathrm{b}}$ * Lucio Toma, ${ }^{\mathrm{c} *}$ Laura Legnani ${ }^{c}$ and Emma Gallo ${ }^{a}$

\footnotetext{
${ }^{a .}$ D. M. Carminati, Dr. D. Intrieri, Prof. E. Gallo. Department of Chemistry, University of Milan. Via C. Golgi 19, 20133 Milan (Italy).E-mail: emma.gallo@unimi.it ${ }^{b}$ Dr. S. Le Gac, Dr. T. Roisnel, Dr. B. Boitrel. Institut des Sciences Chimiques de Rennes, Université de Rennes 1. 263 Avenue du Général Leclerc, 35042 Rennes Cedex (France).

c. Prof. L. Toma, Dr. L. Legnani. Department of Chemistry, University of Pavia. Via Taramelli 12, 27100 Pavia (Italy).
}

Electronic Supplementary Information (ESI) available: NMR Spectra, structural and computational data. See DOI: 10.1039/x0xx00000x

The present report deals with the synthesis and characterisation of $C_{2}$ symmetrical chiral $\mathrm{Fe}(\mathrm{III})$ (porphyrin)OMe catalysts displaying a totem structure, where each section is assigned to a specific catalytic activity. The chiral portions of the porphyrin ligand are constituted by amino acid residues, which form a chiral cavity by surrounding both faces of the porphyrin plane, as clearly displayed by the X-ray structure of one free-base porphyrin.

The Fe(III)(porphyrin)OMe-catalysed cyclopropanation of $\alpha$-methylstyrene by diazo compounds occurred with excellent diastereoselectivities and a modest enantiocontrol. Thus, obtained catalytic results were rationalised by performing a DFT investigation, which will be fundamental in the future modification of the molecular structure of chiral ligands in order to improve their catalytic performance.

\section{Introduction}

The development of eco-friendly catalytic processes to produce valuable chemicals is nowadays a laid down rule rather than added value in line with basic principles of 'green chemistry. ${ }^{1}$ Innovative catalysts, which must combine excellent activity and selectivity with high eco-tolerability, should be designed by choosing an opportune metal/ligand combination. There is a growing scientific interest in the use of first-row transition metals due to their high Earth abundance, economic convenience, low toxicity and versatile catalytic behaviour. ${ }^{2}$ On the other hand, a ligand must contribute to the catalyst performance by ascribing specific peculiarities to the system in terms of shape-, chemo- and stereoselectivity. ${ }^{3}$

Among fine chemicals of a commercial interest, cyclopropane-containing compounds represent a class of active molecules, which can either display biological and pharmaceutical characteristics ${ }^{4,5}$ or be transformed into other relevant compounds by opening reactions of the strained three membered ring. ${ }^{6-10}$ One of the most sustainable methodologies to synthesize cyclopropanes is the one-pot reaction of an alkene with a diazo compound $\left(\mathrm{R}^{1} \mathrm{R}^{2} \mathrm{C}=\mathrm{N}_{2}\right),{ }^{11}, 12$ which has recently been exploited also at industrial level
(Scheme 1). Practical drawbacks related to the hazardous nature of diazo reagents have been overcome by using continuous-flow technologies which permit the safe synthesis of cyclopropanes on a large scale. ${ }^{13-16}$

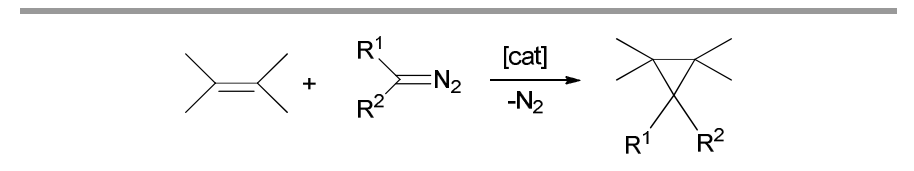

Scheme 1. General scheme of cyclopropanation of alkenes by diazo compounds.

Among all homogeneous catalysts employed to promote alkene cyclopropanations, metal porphyrin complexes have displayed an excellent activity/stability relationship which very often guarantees high TON and TOF values. ${ }^{17-21}$

Porphyrin complexes of first-row transition metals, such as cobalt ${ }^{22-31}$ and iron, ${ }^{32-36}$ are active cyclopropanation catalysts, and in particular iron porphyrin complexes have recently received increased attention from the scientific community. This is because they mimic the catalytic activity of enzymes containing an iron-heme unit, ${ }^{37-39}$ show a cheap, eco-friendly and very active metal ${ }^{40}$ and the low-toxic porphyrin ligand can easily be structurally modified to fine tune the catalytic performance.

We recently reported on the catalytic activity of iron(III) $C_{2}$-symmetrical $\mathrm{Fe}(\mathbf{1}) \mathrm{OMe}$ complex (Figure 1 ) which has promoted the reaction of several styrenes with diazo reagents, producing excellent diastereo- and enantioselectivities (trans/cis up to $99: 1$ and $e e_{\text {trans }}$ up to $87 \%$ ) as well as outstanding TON and TOF values (up to 10000 and 120000 $\mathrm{h}^{-1}$, respectively). ${ }^{41,42}$ The study of the reaction profile highlighted that the reaction stereocontrol was due to a 'totem' ligand structure where three portions were independently responsible for the alkene cyclopropanation. The tetrapyrrolic core of the 'totem' hosts the iron metal which activated the diazo reagent, the $C_{2}$ symmetrical skeleton induced high trans-diastereomeric ratios and the chiral 'hat' was responsible for the enantiocontrol and contributed to the enhancement of the reaction diastereoselectivity. A DFT study of $\mathrm{Fe}(\mathbf{1}) \mathrm{OMe}$-catalysed cyclopropanations revealed the formation of an active intermediate carbene species and clarified the dependence of the stereocontrol on the tridimensional arrangement of the chiral porphyrin ligand. 


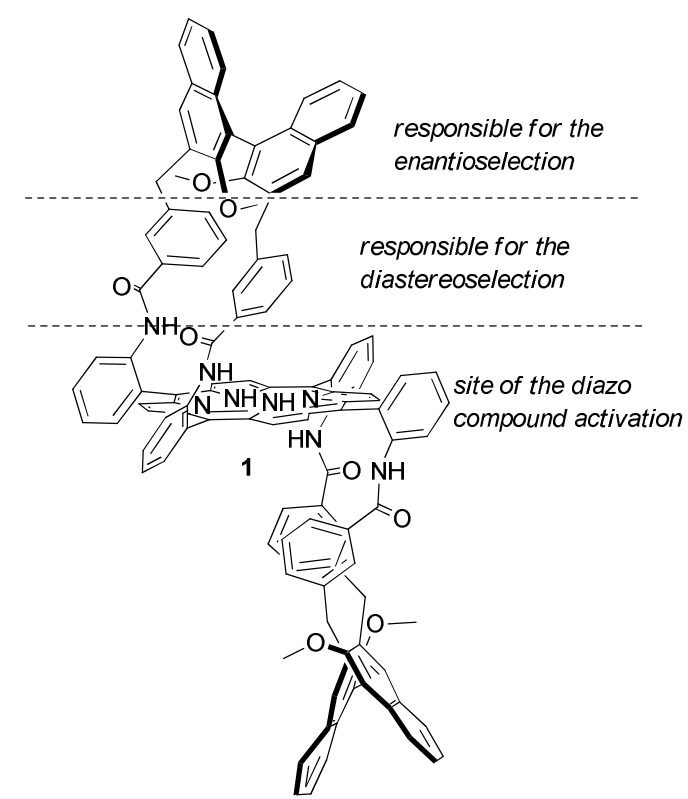

Figure 1. Totem structure of chiral porphyrin 1.

Data described above inspired the synthesis of other $C_{2}$-symmetrical chiral porphyrins where the chiral binaphthyl unit was replaced by an amino acid moiety, which in turn increased the catalyst bio-compatibility without changing the molecular symmetry.

The scientific interest in the synthesis of amino acid/porphyrin conjugates is generally due to their natural tendency to self-assemble into nanoaggregates with interesting chemo-physical characteristics. ${ }^{43}$ The presence of amino acid fragments linked to a porphyrin skeleton plays an important role in the recognition process, ${ }^{44-46}$ enhances the biological uptake of the molecule ${ }^{47}$ and favours the singlet oxygen generation for PDT applications. ${ }^{48,49}$

Amino acid/porphyrin complexes have been poorly employed as homogeneous catalysts and, to the best of our knowledge, they have only been used to mediate oxidation catalytic processes. ${ }^{50-52}$

Herein we report the synthesis and complete characterisation of chiral porphyrins 3, 4 and 5, the synthesis of corresponding iron(III) complexes $\mathrm{Fe}(3) \mathrm{OMe}, \mathrm{Fe}(4) \mathrm{OMe}$ and $\mathrm{Fe}(5) \mathrm{OMe}$ and their catalytic activity in cyclopropanation reactions. In addition, obtained experimental results were rationalised by performing DFT investigations.

\section{Results and discussion}

\section{Synthesis and characterisation of amino ester/porphyrin} conjugates.

As reported in previously published papers, picket porphyrin $\mathbf{2}$ is a suitable starting material to synthesise a large class of strapped porphyrins, including porphyrin 1, in good yields. ${ }^{41,53}$ Achieved data indicate that the length of the strap can be tuned by selecting the number of atoms between the two pickets and that these two pickets are flexible enough to be linked on one single atom to form two additional macrocycles above and below the porphyrin plane. Therefore, in order to synthesize a larger pool of chiral molecules, the benzylic functionality of porphyrin $\mathbf{2}$ was reacted with the primary amino group of either chiral amines or natural amino ester compounds.

Thus in a typical reaction, porphyrin $\mathbf{2}$ was heated in presence of $\mathrm{K}_{2} \mathrm{CO}_{3}$ and $\mathrm{Nal}$ with $(L)$-alanine tert-butyl ester, $(S)$ - $\alpha$-methylbenzylamine, and ( $L$ )-phenylalanine methyl ester to obtain the corresponding strap porphyrins 3, 4, and 5 respectively in yields up to $67 \%$ (Scheme 2 ).

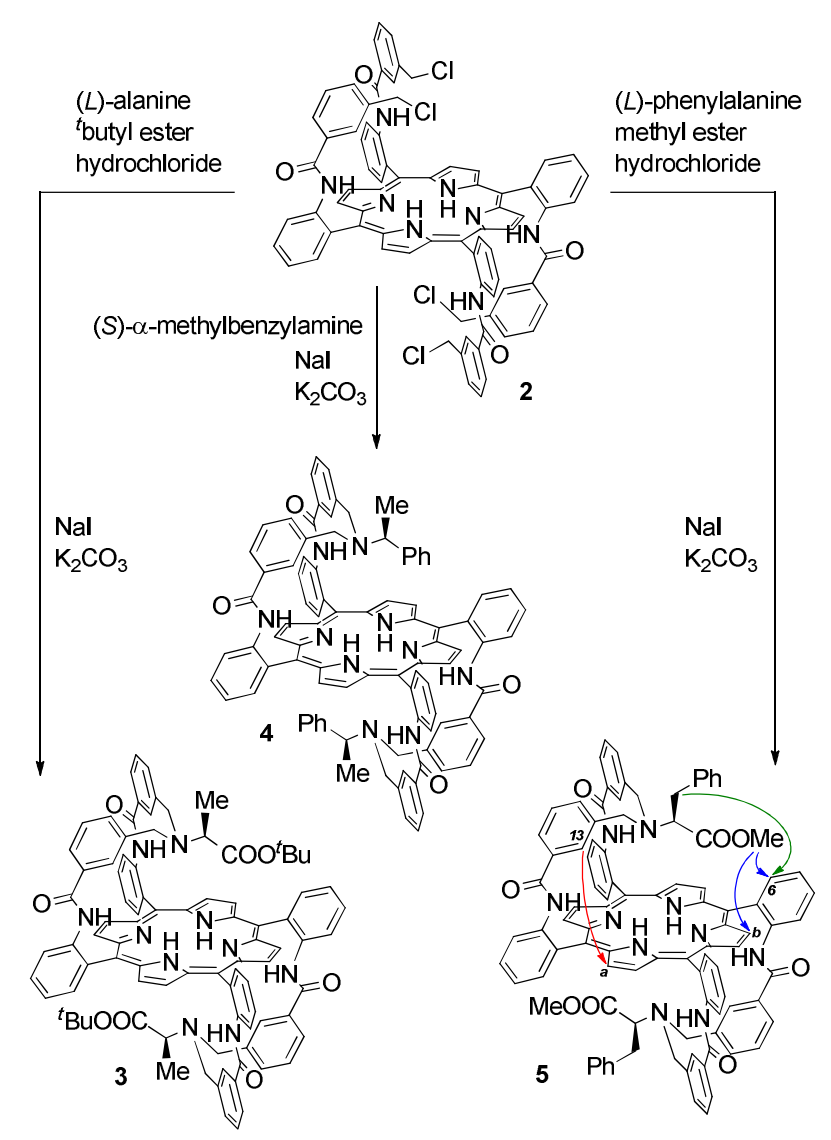

Scheme 2. Synthesis of porphyrins $\mathbf{3}, \mathbf{4}$ and $\mathbf{5}$.

As already reported for porphyrin $1,{ }^{41,42}$ the ${ }^{1} \mathrm{H}$ NMR pattern of this type of ligand can help us to have an idea of their structure in solution by analysing the chemical shift of characteristic protons, as those of the methyl group of alanine, methylene group of phenylalanine or ester group, both in the native amino ester and once grafted on the porphyrin skeleton.

It should be noted that all the protons placed in the alpha positions with respect to the stereogenic centre are shifted towards lower ppm values ( $\Delta \delta \sim 2 \mathrm{ppm}$, see SI). A deeper analysis of the molecular structure of $\mathbf{5}$ by using Nuclear Overhauser effect (NOE) spectroscopy (vide infra for details) clearly indicates that the aromatic cycles of the linkers are oriented in solution towards the tetrapyrrolic core in contrast with what observed for porphyrin 1 (Figure 2) where the NMR study disclosed that the two benzyl units pointed outside the porphyrin plane. $^{41}$ 
In the case of porphyrin 5, single crystals suitable for X-ray crystallography were also obtained by slow evaporation of a solution of 5 in a $\mathrm{CH}_{2} \mathrm{Cl}_{2} /{ }^{n}$ hexane $=1: 6$ mixture.

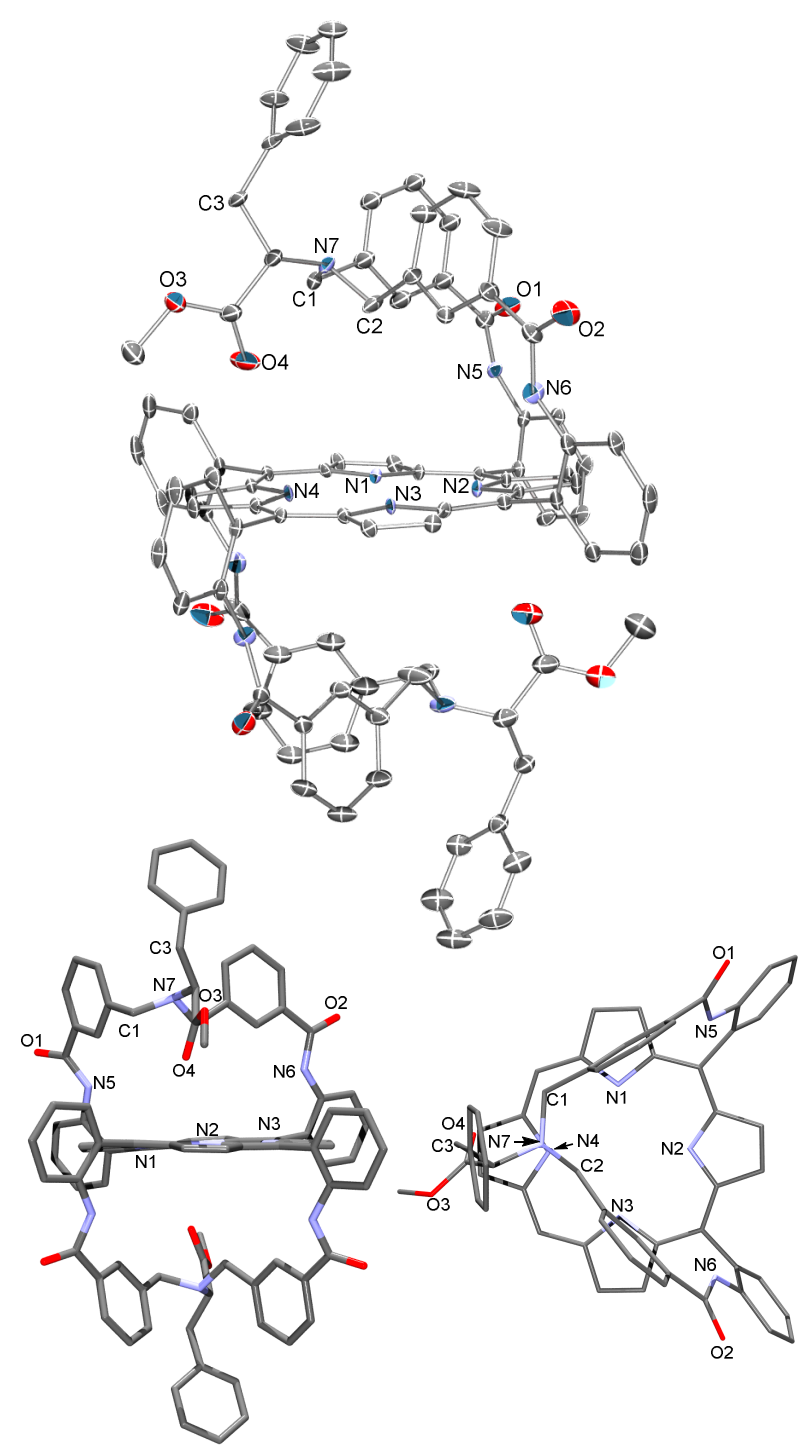

Figure 2. X-ray structure of free-base porphyrin $\mathbf{5}$ (conformation A). Top: perspective ORTEP view ( $30 \%$ level of probability). Bottom, left: Rods view perpendicular to the straps. Right: Rods apical view (bottom strap omitted).

As reported in Figures 2 and 3 there are two different conformations of porphyrin $\mathbf{5}$ in the asymmetric unit cell. These two conformations A and B mainly differ by only one strap with the ester residue pointing either inside the cavity (Figure 2, conformation A) or outside the cavity (Figure 3, conformation B).

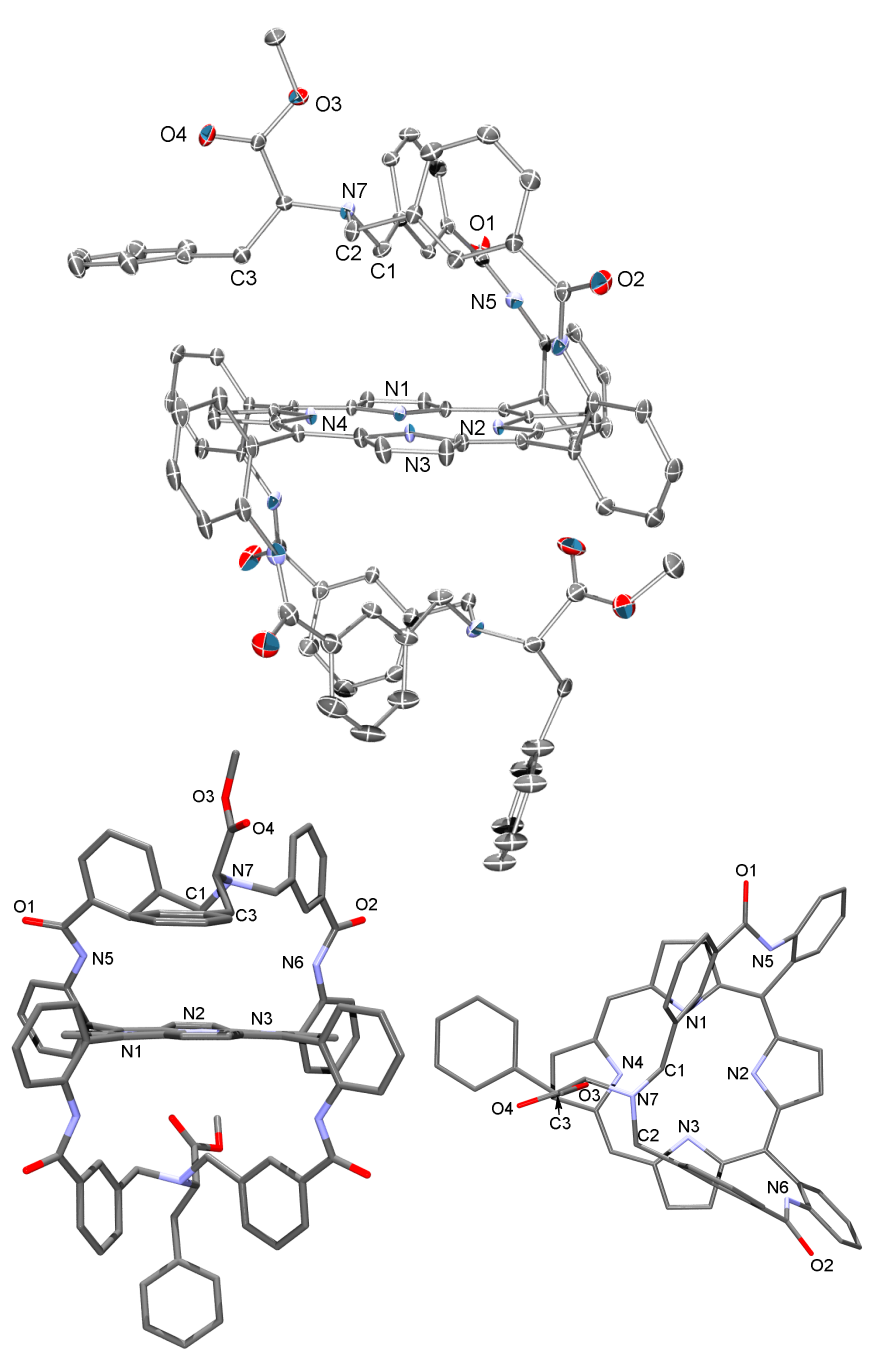

Figure 3. X-ray structure of free-base porphyrin $\mathbf{5}$ (conformation B). Top: perspective ORTEP view ( $30 \%$ level of probability). Bottom, left: Rods view perpendicular to the straps. Right: Rods apical view (bottom strap omitted).

In solution, 2D NMR NOE correlations (see SI), observed between the aromatic protons labelled ' 13 ' and the $\beta$-pyrrolic protons labelled ' $a$ ' (Scheme 2, red arrows), indicated a 'pinched' conformation of the strap lying above the porphyrin, in agreement with the X-ray structures. NOE correlations were also observed between OMe protons and (i) meso-aromatic protons labelled ' 6 ' and (ii) $\beta$-pyrrolic protons labelled ' $b$ ' (blue arrows), as well as between $\mathrm{CH}_{2} \mathrm{Ph}$ protons and $\beta$-pyrrolic protons labelled ' $b$ ' (green arrows). This showed that the two types of conformations $\mathbf{A}$ and $\mathbf{B}$ coexist in solution and are averaged on the NMR time scale.

On the other hand, in solid state the two benzylic groups ( $\mathrm{C} 1$ and $\mathrm{C} 2$ ) linked by the amine nitrogen atom (N7) of the amino ester were clearly oriented inside the cavity in conformation $\mathbf{A}$ (Figure 2). This inwards conformation projects the amino ester residues above the coordination site of the macrocycle with the side chain rejected outside the cavity. The two phenyl rings from the side chain are oriented at $63.0^{\circ}$ and $62.1^{\circ}$ of the mean porphyrin plane.

The atom of the amino ester closest to the porphyrin plane was the oxygen atom of the carbonyl group $\mathrm{O} 4$ at $4.907 \AA$ from the centre of the N4-core and $2.903 \AA$ from the 24 -atom mean 
plane (24-MP). However, as seen on the apical view (Figure 2, bottom right), the complete amino ester functionality was significantly off-centred with its nitrogen atom N7 almost at the apical position of one nitrogen atom of a pyrrole cycle, N4. The macrocycle plane was slightly ruffled (Figure 2, bottom left) as indicated by the angle between the two pairs of diametrically opposed pyrrole units measured as $6.0^{\circ}$ and $4.5^{\circ}$. The two straps were similarly bent over the centre of the porphyrin core with angles of $59.4^{\circ}$ and $57.8^{\circ}$ with the mean plane of the straps being calculated by incorporation of all the atoms except those of the amino ester residue.

When conformations $\mathbf{A}$ and $\mathbf{B}$ were compared, the most striking difference in conformation B (Figure 3) was the fact that the spatial location of the ester and lateral chain groups was inverted. In conformation B, the ester group was oriented outside with 04 located at $7.921 \AA$ from the centre of the N4core and $6.399 \AA$ from the 24-atom mean plane (24-MP). The phenyl ring of one lateral chain (top strap in Figure 3 ) was almost parallel to the mean porphyrin plane with an angle of only $6.48^{\circ}$ and a distance of its centroid at the mean porphyrin plane of $3.527 \AA$. The two phenyl rings of the lateral chains in this conformation B were at $66.84^{\circ}$ one from each other. The bottom right apical view of conformation B in Figure 3 clearly shows that the centroid of the lateral chain aromatic group was far away (7.156 ̊) from the centroid of the N4 core of the porphyrin. In this second conformation $\mathbf{B}$, the angles of the two straps with the mean porphyrin plane were quasi identical $\left(52.52^{\circ}\right.$ and $\left.52.97^{\circ}\right)$ but slightly smaller than in conformation $\mathbf{A}$.

\section{Synthesis, characterisation and catalytic activity of $\mathrm{Fe}$ (III)(porphyrin)OMe complexes.}

Complexes $\mathrm{Fe}(3) \mathrm{OMe}$, Fe(4)OMe and $\mathrm{Fe}(5) \mathrm{OMe}$ were synthesised by reacting porphyrins $\mathbf{3}, \mathbf{4}$ and 5 with iron bromide and by following the experimental procedure already reported for the synthesis of $\mathrm{Fe}(\mathbf{1}) \mathrm{OMe} .^{41,42}$

Complex $\mathrm{Fe}(3) \mathrm{OMe}$ was first tested as the catalyst of $\alpha$-methylstyrene cyclopropanation by using either ethyl diazoacetate (EDA) or benzyl diazoacetate (BDA) as the diazo reagent (Table 1). It should be noted that, as previously reported for $\mathrm{Fe}(\mathbf{1})$ OMe-catalysed cyclopropanations, ${ }^{41}$ the reaction performed well without employing an alkene excess however a small amount of diazo reagent excess was used.

As reported in Table 1, even if the consumption of the alkene occurred in a few minutes, complex Fe(3)OMe displayed a modest catalytic activity and desired cyclopropanes 6 and 7 were obtained from moderate to good yields. The reaction performed better in the presence of EDA than BDA and the best yield of $90 \%$ (Table 1 , entry 3 ) was achieved by slowly adding EDA in order to limit the formation of side-product 8.
Table 1. Fe(3)OMe-catalysed cyclopropanation of $\alpha$-methylstyrene by either EDA or BDA. $^{[a]}$

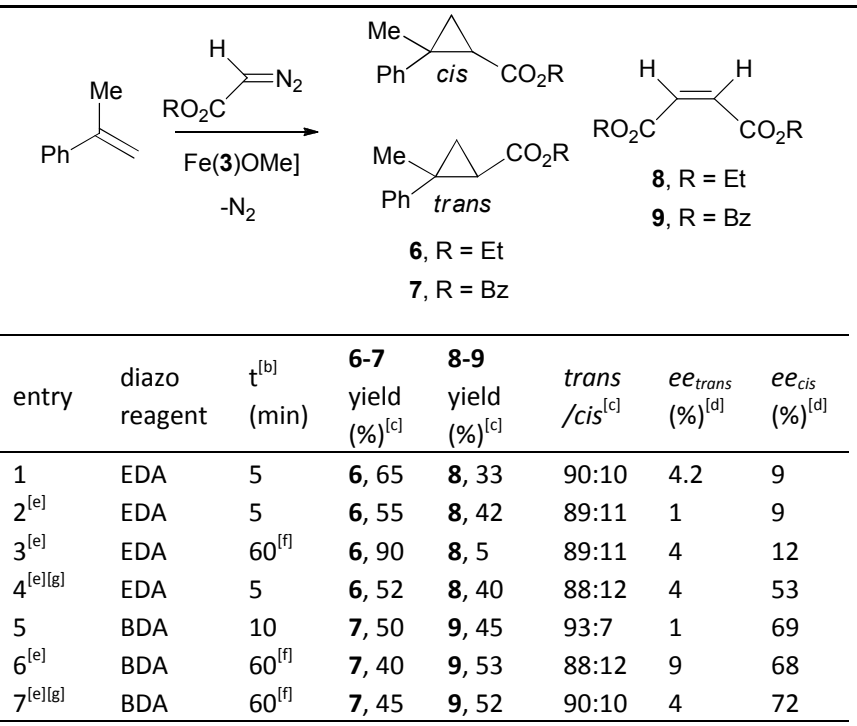

[a] Catalyst/ $\alpha$-methylstyrene/diazo compound=1:1000:1100 in $2.5 \mathrm{~mL}$ of toluene at $25^{\circ} \mathrm{C}$. [b] Time required for the diazo compound conversion monitored by IR spectroscopy. [c] Determined by ${ }^{1} \mathrm{H}$ NMR (2,4-dinitrotoluene as the internal standard). [d] Enantiomeric excess of trans $(S, S)$ and cis $(S, R)$ isomer determined by HPLC (DAI-CEL CHIRALCEL, IB, ${ }^{n}$ hexane/'propanol=99.75:0.25). [e] Run in the presence of molecular sieves ( $4 \AA$ ). [ $\mathrm{f}$ ] Diazo compound was added by a syringe pump. [g] Reaction performed at $0^{\circ} \mathrm{C}$.

The trans-diastereoselectivity of the reaction between EDA and $\alpha$-methylstyrene (Table 1 , entries $1-4$ ) was always good and similar to those already observed in the presence of catalysts $\mathrm{Fe}(\mathbf{1}) \mathrm{OMe}$ and $\mathrm{Fe}(\mathbf{2}) \mathrm{OMe} .^{41,42}$ This data confirmed that the diastereocontrol was principally due to the tridimensional structure of porphyrin $\mathbf{2}$ independently from the nature of the chiral 'hat' linked to 2. Unfortunately, catalyst $\mathrm{Fe}(\mathbf{3}) \mathrm{OMe}$ was not very effective in controlling the reaction enantioselectivity (Table 1 , entries $1-3$ ) and only when the reaction was run at $0^{\circ} \mathrm{C}$ (Table 1 , entry 4 ) $53 \%$ of $e e_{\text {cis }}$ (and $4 \%$ of $e e_{\text {trans }}$ ) was achieved. It should be noted that only the minor cis-isomer of $\mathbf{6}$ was formed with a moderate enantiocontrol in contrast to what was observed in the $\mathrm{Fe}(2) \mathrm{OMe}$-catalysed reactions where the trans-isomer was formed with both excellent diastereo- and enantioselectivity. ${ }^{41,42}$

In order to improve the stereocontrol, the cyclopropanation of $\alpha$-methylstyrene was performed by using the more sterically hindered BDA as the carbene source. The best result was obtained by running the reaction at $25^{\circ} \mathrm{C}$ (Table 1 , entry 5) where the trans/cis ratio of 93:7 was associated to $69 \%$ of $e e_{c i s}$. The reaction did not perform better either by adding the diazo reagent by a syringe pump (Table 1 , entry 6 ) or by decreasing the temperature from 25 to $0^{\circ} \mathrm{C}$ where only a slight increase of the enantiomeric excess of the cis-isomer was observed (Table 1, entry 7).

In order to investigate a possible catalytic role of the ester functionality onto the amino acid residue, the reaction between EDA and $\alpha$-methylstyrene was run in the presence of $\mathrm{Fe}(4) \mathrm{OMe}$ catalyst (Scheme 2) in which the chiral portion derived from (S)- $\alpha$-methylbenzylamine. The cyclopropanation, performed at $25^{\circ} \mathrm{C}$ with a catalyst/ $\alpha$-methylstyrene/EDA ratio 
of 1:1000:1100, produced compound 6 in 75\% yield, trans/cis ratio of $90: 10,8 \% e e_{\text {trans }}$ and $50 \% e e_{\text {cis. }}$. This result was in accord with that registered for $\mathrm{Fe}(3) \mathrm{OMe}$-catalysed reactions to indicate that the ester functionality did not play a specific role in controlling the reaction enantioselectivity.

Finally, the same catalytic reaction was run in the presence of $\mathrm{Fe}(\mathbf{5}) \mathrm{OMe}$ (Scheme 2) which showed a chiral portion derived from methyl ester of $(L)$-phenylalanine rather than from ${ }^{t}$ butyl ester of $(L)$-alanine as occurred in $\mathrm{Fe}(3) \mathrm{OMe}$. Achieved results were in line with those discussed above and cyclopropane 6 was formed with $78 \%$ yield, $95: 5$ of trans/cis ratio, $9 \%$ ee trans and $54 \% e e_{c i s}$. This data indicated that a more sterically hindered benzyl group onto the stereogenic centre did not confer a more rigid orientation to the two chiral lateral pickets with a consequent scarce differentiation of the two enantiomeric reaction paths.

Then, to rationalize catalytic data discussed up to now, a DFT study was carried out and obtained results are discussed below.

\section{DFT study of the cyclopropanation reaction.}

The X-ray structure of compound $\mathbf{5}$ shows a bent orientation of the chiral amino acid moiety towards the porphyrin system; this should have led to a heavy influence on the stereochemical outcome of the reactions catalysed by its iron complex $\mathrm{Fe}(5) \mathrm{OMe}$, as well as by the $\mathrm{Fe}(3) \mathrm{OMe}$ and $\mathrm{Fe}(4) \mathrm{OMe}$ complexes, which reasonably share the same geometry of the molecular skeleton, so inducing much greater ee values than those experimentally observed. However, the bent geometry leaves very little room to host, during the cyclopropanation reaction, the carbene, originated by the EDA or BDA attacks, and the approaching $\alpha$-methylstyrene. This strongly suggests that, during the catalytic process, the ligands geometry might not correspond to that determined through the X-ray analysis for 5. A theoretical approach can be of help in the search of all the low-energy conformers of ligands 3-5 and allows to detect the geometries more suitable to host the reacting entities, eventually suggesting the reasons of the observed low enantioselectivity. Thus, using the Gaussian09 package, ${ }^{54}$ a conformational study was initially performed on the free ligands and successively extended to the transition state of the cyclopropanation reaction that their iron methoxy complexes catalyse. All the calculations were carried out within the density functional approach at the B3LYP ${ }^{55,56}$ level with the 6-31G(d) basis set for all atoms except the effective core potential LanL2DZ basis set used for iron, a computational level already found adequate for other metal porphyrin complexes. ${ }^{27,41,57}$

As reported above, the asymmetric unit cell of compound $\mathbf{5}$ contains the two independent conformations $\mathbf{A}$ and $\mathbf{B}$. The two straps of conformation $\mathbf{A}$ are almost similar as also indicated by the torsional angles defining its geometry (Table S1). Conversely, though the orientation of the strap in the upper side of conformation $\mathbf{B}$ corresponds to that found in $\mathbf{A}$, the arrangement of the strap in its lower side are quite different; the skeleton is roughly enantiomeric with respect to the upper strap and, as already stated, the amino acid phenyl group faces one of the pyrrole rings instead of pointing away from the molecular core. When optimized at the B3LYP/6-31G(d) level, the two crystallographic conformations $\mathbf{A}$ and $\mathbf{B}$ converge to distinct conformers, 5A and 5B (Table S1), the former being more stable by $0.81 \mathrm{kcal} / \mathrm{mol}$ than the latter. This indicates that the geometrical motif present in $\mathbf{5 A}$ and in the upper side of 5B if slightly favoured over the motif present in the lower side of $\mathbf{5 B}$ and that the packing crystallographic forces are able to force a strap in a non optimal arrangement. It cannot be excluded that the straps of compound $\mathbf{5}$ might assume other geometrical arrangements different from those present in its crystal structure and, to explore this possibility, the singlehandled structure $\mathbf{1 0}$ (Figure 4) was initially used. Compound 10 is devoid of the chiral moiety, replaced by a methyl group (named $\mathrm{C} \alpha$ in the Figure 4), but shares the common features of compounds 3-5 and can be considered a simplified model for all of them. Although it contains only one strap, its intrinsical conformational preferences should correspond to those of the entire ligands, as already shown in similar cases. ${ }^{27}$, 41

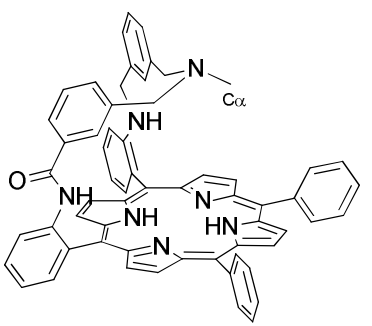

10

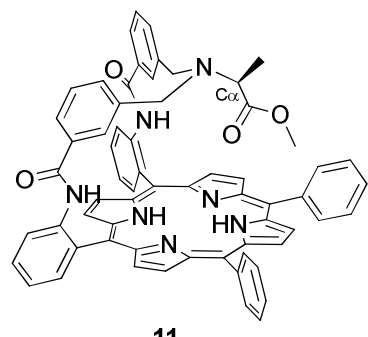

11

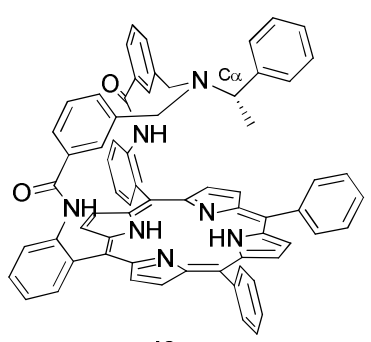

12
Figure 4. Model compounds 10-12.

Optimization of all the predictable starting geometries of $\mathbf{1 0}$ allowed to locate, besides conformer 10A, corresponding to the handle geometry present in $\mathbf{5 A}$ and in the upper side of $\mathbf{5 B}$, and its conformational enantiomer 10B, corresponding to the handle present in the lower side of $\mathbf{5 B}$, a number of other conformers. Some of them, 10C-E, are only about $2 \mathrm{kcal} / \mathrm{mol}$ less stable than 10A-B and present interesting geometrical features (Figure 5 and Table S2). In conformers 10C-E the methyl group, mimic of the $\alpha$ carbon atom of the amino acid moiety, points away from the molecular core leaving an empty space above the porphyrin. In fact, the distance of $\mathrm{C} \alpha$ from the porphyrin centre $(10.92,9.07$, and $9.07 \AA$ for 10C, 10D, and $10 \mathrm{E}$, respectively) is much greater than in the crystallographic conformations A and B (5.56-5.90 Å). Conformers 10D and 10E are a couple of conformational enantiomers while conformer $10 \mathrm{C}$, having a plane of symmetry, is more symmetrical. 


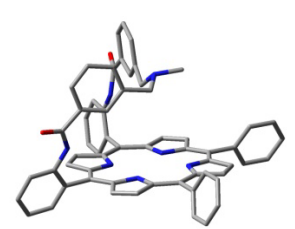

10A

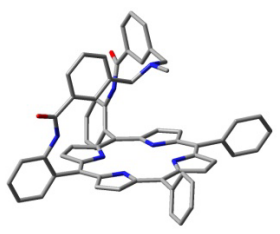

$10 B$

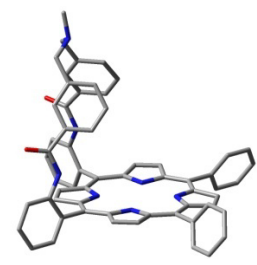

$10 \mathrm{C}$

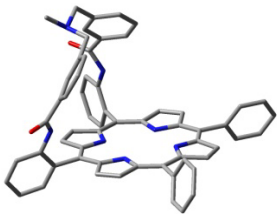

10D

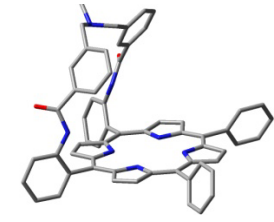

$10 \mathrm{E}$
Figure 5. Three-dimensional plots of the preferred conformers of the model singlebinaphthyl-handled porphyrin 10.

Attention was then turned towards the stereoisomeric transition states (TSs) of the cyclopropanation reaction catalysed by the porphyrin iron methoxy complexes. Starting from the already described ${ }^{41}$ TSs for the trans and cis attack of $\alpha$-methylstyrene to the terminal carbene species deriving from $\mathrm{Fe}(\mathrm{TPP})(\mathrm{OMe})$ (TPP = dianion of tetra-phenyl porphyrin), the handle of 10 in the 10A-E geometries was built around them. In each case, two substantially different orientations of the carbene moiety were envisaged, one with its ethyl group pointing inside the handle and the other one with this group outside it. A neat preference was found in all the cases for the outside orientation of the carbene ethyl group so the following discussion refers only to this arrangement (Figure 6 and Table S2). The large room present in 10D and $10 \mathrm{E}$ above the porphyrin allows them to well accommodate the approaching $\alpha$-methylstyrene and the carbene, making the corresponding TSs preferred over those originated from 10A-C. In particular, the fact that the geometry of the free ligand is almost unchanged in 10D-TS and 10E-TS complexes indicates that little strain is present in them. On the contrary, all the TSs deriving from $10 \mathrm{~A}$ and $10 \mathrm{~B}$, less stable by $7-8 \mathrm{kcal} / \mathrm{mol}$ than those deriving from $10 \mathrm{D}$ and $10 \mathrm{E}$, show a severe steric strain in the handle that is pushed away from the porphyrin, as indicated by the severe changes in the torsional angle values and by the $C \alpha /$ porphyrin distance increased by almost $3 \AA$ as respect to the free ligand (Table S2). The TSs derived from 10C are less stable than those derived from 10D-E, too, although to a lesser extent than those derived from 10A-B. Their steric strain is mainly due to the lateral meta-substituted benzo groups of the pickets which are too close one to the other for an optimal hosting of the reacting entities. It is worthy pointing out that, in agreement with the experimental data, in all the cases the trans-TSs are preferred over the cis-TSs.
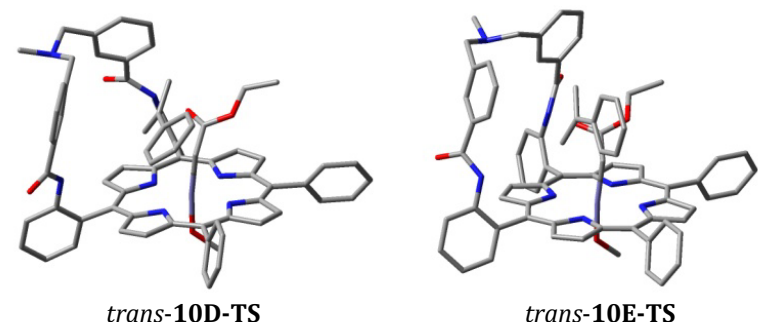

trans-10E-TS

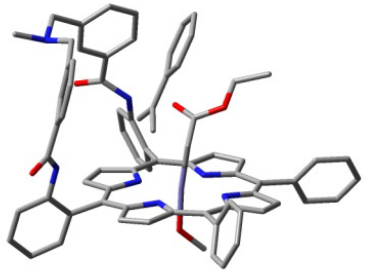

cis-10D-TS

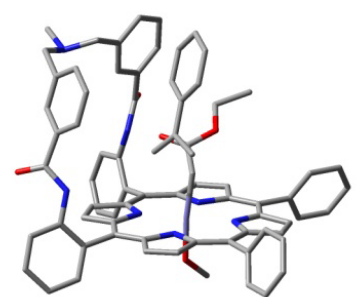

cis-10E-TS
Figure 6. Three-dimensional plots of the lowest energy transition states for the trans and cis attack of $\alpha$-methylstyrene to the terminal carbene species deriving from the model ligand 10.

Finally, the stereogenic center of the model ligand $\mathbf{1 1}$ (Figure 4), which contains the common features of ligands $\mathbf{3}$ and $\mathbf{5}$ and can be considered a suitable model for both of them, was built in the $S$ configuration around $C \alpha$ of 10D-TS and 10E-TS complexes, using them twice, as such and as the mirror image, to obtain eight TS starting geometries, able to furnish the four $(1 R, 2 R), \quad(1 S, 2 S), \quad(1 R, 2 S), \quad$ and $(1 S, 2 R)$ stereoisomeric cyclopropane reaction products. The main energetic and geometrical features of the eight optimized TSs are reported in Table S3 whereas the three-dimensional plots of the two most stable trans and cis TSs are reported in Figure 7. Once again, in agreement with the observed experimental data, the trans-TSs resulted significantly more stable than the cis-TSs. Moreover, the theoretical calculations reproduce the experimentally observed preference for the $(1 S, 2 S)$ and $(1 S, 2 R)$ stereoisomers of the trans and cis cyclopropane products, respectively. The observed enantioselectivity, very poor for the trans product and better but not excellent for the cis one, is justified by a limited influence of the chiral moiety, as expected by the fact that $\mathrm{C} \alpha$ points away from the reaction site.

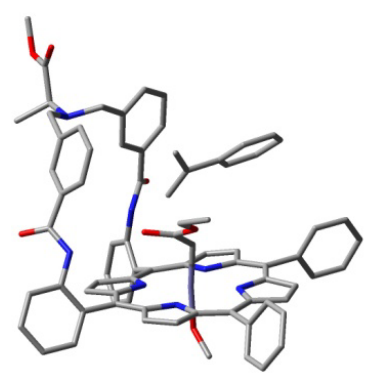

trans- $(S, S)-11 \mathrm{E}-\mathrm{TS}$

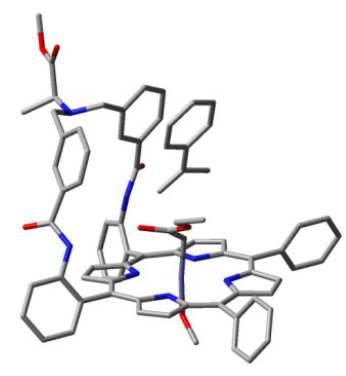

cis- $(S, R)-\mathbf{1 1 E}-$
Figure 7. Three-dimensional plots of the lowest energy transition states for the trans and cis attack of $\alpha$-methylstyrene to the terminal carbene species deriving from the model ligand 11. 
A similar procedure was repeated by building around $\mathrm{C} \alpha$ of the 10D-TS and 10E-TS complexes the stereogenic centre of the ligand 12 (Scheme 3), making it a model for 4 . The computational data, reported in Table S4, are very similar to those found for 11, in agreement with the experimental behaviour of ligand $\mathbf{4}$ comparable with that of ligands $\mathbf{3}$ and $\mathbf{5}$.

\section{Experimental}

General procedures. Unless otherwise specified, all reactions were carried out under nitrogen or argon atmosphere employing standard Schlenk techniques and magnetic stirring. Porphyrin $\mathbf{2}^{58}$ was synthesised according to literature procedure. Toluene, THF and $\alpha$-methylstyrene were purified by using standard methods and stored under nitrogen atmosphere. Anhydrous DMF and all other starting materials were commercial products used as received. NMR spectra were recorded at room temperature on a Bruker Avance 300DRX, operating at $300 \mathrm{MHz}$ for ${ }^{1} \mathrm{H}$ and at $75 \mathrm{MHz}$ for ${ }^{13} \mathrm{C}$, or on a Bruker Avance 400-DRX spectrometer, operating at $400 \mathrm{MHz}$ for ${ }^{1} \mathrm{H}$ and at $100 \mathrm{MHz}$ for ${ }^{13} \mathrm{C}$, or on a Bruker Avance 500-DRX spectrometer operating at $500 \mathrm{MHz}$ for ${ }^{1} \mathrm{H}$ and at $125 \mathrm{MHz}$ for ${ }^{13} \mathrm{C}$. Chemical shifts (ppm) are reported relative to TMS. The ${ }^{1} \mathrm{H}$ NMR signals of the compounds described in the following were identified by $2 \mathrm{D}$ NMR techniques. Infrared spectra were recorded on a Varian Scimitar FTS 1000 spectrophotometer. UV/Vis spectra were recorded on an Agilent 8453E instrument. Elemental analyses and mass spectra were recorded in the analytical laboratories of Milan and Rennes 1 Universities. XRD were collected on a D8 VENTURE Bruker AXS diffractometer.

Synthesis of Porphyrin 3. Porphyrin $2\left(0.080 \mathrm{~g}, 6.22 \cdot 10^{-5} \mathrm{~mol}\right)$, $(L)$-alanine tert-butyl ester hydrochloride $\left(0.056 \mathrm{~g}, 3.11 \cdot 10^{-4}\right.$ $\mathrm{mol}), \mathrm{Nal}\left(0.093 \mathrm{~g}, 6.22 \cdot 10^{-4} \mathrm{~mol}\right)$ and $\mathrm{K}_{2} \mathrm{CO}_{3}\left(0.172 \mathrm{~g}, 1.24 \cdot 10^{-3}\right.$ mol) were dissolved in $72.0 \mathrm{~mL}$ of THF and $8.0 \mathrm{~mL}$ of DMF under argon. The mixture was refluxed under stirring for 8 hours until the complete consumption of $\mathbf{2}$, which was monitored by TLC. Then, the solvent was evaporated to dryness and $20.0 \mathrm{~mL}$ of $\mathrm{CH}_{2} \mathrm{Cl}_{2}$ was added to the residue. The organic phase was extracted with $0.5 \mathrm{M} \mathrm{HCl}$ solution (three times with $20.0 \mathrm{~mL}$ each time), water $(20.0 \mathrm{~mL}$ added three times) and then dried over $\mathrm{NaSO}_{4}$ and filtered. The filtrate was evaporated to dryness under reduced pressure and the crude purified by flash chromatography (silica gel, $15 \mu \mathrm{m}, 0.3 \%$ $\mathrm{MeOH}$ in $\mathrm{CH}_{2} \mathrm{Cl}_{2}$ ) to obtain a dark purple solid (49,0 mg, 55\%). ${ }^{1} \mathrm{H}$ NMR (500 MHz, $\mathrm{CDCl}_{3}, 298 \mathrm{~K}$ ): (see SI for attribution) $\delta 8.96$ $\left(\mathrm{m}, 4 \mathrm{H}, \mathrm{H}_{\beta p y r}\right), 8.93\left(\mathrm{~d}, 2 \mathrm{H}, J=4.4 \mathrm{~Hz}, \mathrm{H}_{\beta p y r}\right), 8.82\left(\mathrm{~s}, 2 \mathrm{H}, \mathrm{H}_{\beta p y r}\right)$, $8.83\left(\mathrm{~d}, 2 \mathrm{H}, J=7.6 \mathrm{~Hz}, \mathrm{H}^{3}\right), 8.66\left(\mathrm{~d}, 2 \mathrm{H}, J=7.6 \mathrm{~Hz}, \mathrm{H}^{3^{\prime}}\right), 8.12(\mathrm{~d}$, $4 \mathrm{H}, J=7.6 \mathrm{~Hz}, \mathrm{H}^{6}$ and $\left.\mathrm{H}^{6^{\prime}}\right), 7.91\left(\mathrm{~m}, 4 \mathrm{H}, \mathrm{H}^{4}\right.$ and $\left.\mathrm{H}^{4^{\prime}}\right), 7.60(\mathrm{~m}, 4 \mathrm{H}$, $\mathrm{H}^{5}$ and $\left.\mathrm{H}^{5^{\prime}}\right), 7.30\left(\mathrm{~d}, 2 \mathrm{H}, J=7.6 \mathrm{~Hz}, \mathrm{H}^{9}\right), 7.20(\mathrm{~d}, 2 \mathrm{H}, J=7.6 \mathrm{~Hz}$, $\mathrm{H}^{9^{\prime}}$ ), $7.16(\mathrm{~s}, 2 \mathrm{H}, \mathrm{HCONH}), 7.04\left(\mathrm{~s}, 2 \mathrm{H}, H \mathrm{CONH}^{\prime}\right), 6.81(\mathrm{t}, 2 \mathrm{H}$, $\left.J=7.6 \mathrm{~Hz}, \mathrm{H}^{10}\right), 6.77\left(\mathrm{~d}, 2 \mathrm{H}, J=7.6 \mathrm{~Hz}, \mathrm{H}^{11}\right), 6.74(\mathrm{t}, 2 \mathrm{H}, J=7.7 \mathrm{~Hz}$, $\left.\mathrm{H}^{10^{\prime}}\right), 6.62\left(\mathrm{~d}, 2 \mathrm{H}, J=7.6 \mathrm{~Hz}, \mathrm{H}^{11^{\prime}}\right), 4.41\left(\mathrm{~s}, 2 \mathrm{H}, \mathrm{H}^{13}\right), 4.03(\mathrm{~s}, 2 \mathrm{H}$, $\left.\mathrm{H}^{13}\right), 2.08\left(\mathrm{~d}, 2 \mathrm{H}, J^{2}=13.1 \mathrm{~Hz}, \mathrm{H}^{14 \mathrm{~A}}\right), 1.82\left(\mathrm{q}, 2 \mathrm{H}, J=6.8 \mathrm{~Hz}, \mathrm{H}^{15}\right)$, $1.26\left(\mathrm{~s}, 18 \mathrm{H}, \mathrm{H}^{17}\right), 0.84\left(\mathrm{~d}, 2 \mathrm{H}, J^{2}=13.0 \mathrm{~Hz}, \mathrm{H}^{14 \mathrm{~B}}\right), 0.61$ (bs, $4 \mathrm{H}$, $\mathrm{H}^{14 \mathrm{~A}^{\prime}}$ and $\left.\mathrm{H}^{14 \mathrm{~B}^{\prime}}\right),-0.88\left(\mathrm{~d}, 6 \mathrm{H}, J=6.8 \mathrm{~Hz}, \mathrm{H}^{16}\right),-2.33 \mathrm{ppm}(\mathrm{s}, 2 \mathrm{H},-$ $\mathrm{NH}_{2}$ ). ${ }^{13} \mathrm{C}$ NMR $\left(125 \mathrm{MHz}, \mathrm{CDCl}_{3}, 298 \mathrm{~K}\right): \delta 171.7,165.0,164.7$, $139.0,138.9,138.8,138.3,134.2,134.0,133.6,132.2,131.7$,
$131.2,130.6,130.5,128.6,128.5,126.9,126.3,124.2,123.8$, 123.7, 123.4, 121.9, 121.6, 115.5, 115.4, 80.8, 57.5, 52.4, 31.7, 28.1, 10.1 ppm. UV-Vis: $\lambda_{\max }\left(\mathrm{CH}_{2} \mathrm{Cl}_{2}\right): \mathrm{nm} 422,514,547,587$, $642\left(\log \varepsilon_{\mathrm{M}} 5.60,4.11,3.46,3.60\right.$ and 3.08). IR $\left(\mathrm{CH}_{2} \mathrm{Cl}_{2}\right): v=3683$ $(w), 3423(w), 3315(w), 2978(w), 2932(w), 1727(w), 1682$ (w), $1606(w), 1582(w), 1522(w), 1447(w), 1308(w), 1146$ $\mathrm{cm}^{-1}(w)$. IR (ATR): v=3725 (w), $3005(w), 1684(w), 1507(w)$, $1276(w), 1261(w), 758(w), 751 \mathrm{~cm}^{-1}(w)$. Elem. Anal. Calcd. for $\mathrm{C}_{90} \mathrm{H}_{80} \mathrm{~N}_{10} \mathrm{O}_{8}$ : C, 75.61; H, 5.64; N, 9.80. Found: C, 75.47; $\mathrm{H}$, 5.73; N, 9.62. ESI: $m / z=1429.7\left[\mathrm{M}^{+}\right]$.

Synthesis of Porphyrin 4. Porphyrin 2 ( $\left.0.500 \mathrm{~g}, 3.89 \cdot 10^{-4} \mathrm{~mol}\right)$, (S)- $\alpha$-methylbenzylamine $\left(0.235 \mathrm{~g}, 1.94 \cdot 10^{-4} \mathrm{~mol}\right)$, Nal $(0.583 \mathrm{~g}$, $\left.3.89 \cdot 10^{-3} \mathrm{~mol}\right)$ and $\mathrm{K}_{2} \mathrm{CO}_{3}\left(1.08 \mathrm{~g}, 7.78 \cdot 10^{-3} \mathrm{~mol}\right)$ were dissolved in $450.0 \mathrm{~mL}$ of THF and $50.0 \mathrm{~mL}$ of DMF under argon. The mixture was refluxed under stirring for 6 hours until the complete consumption of $\mathbf{2}$, which was monitored by TLC. Then, the solvent was evaporated to dryness and $50.0 \mathrm{~mL}$ of $\mathrm{CH}_{2} \mathrm{Cl}_{2}$ was added to the residue. The organic phase was extracted with $0.5 \mathrm{M} \mathrm{HCl}$ solution ( $50.0 \mathrm{~mL}$ added three times), water ( $50.0 \mathrm{~mL}$ added three times) and then dried over $\mathrm{NaSO}_{4}$ and filtered. The filtrate was evaporated to dryness under reduced pressure and the crude purified by flash chromatography (silica gel, $15 \mu \mathrm{m}, 0.2 \% \mathrm{MeOH}$ in $\mathrm{CH}_{2} \mathrm{Cl}_{2}$ ) to obtain a dark purple solid (0.359 g, 67\%). ${ }^{1} \mathrm{H}$ NMR (400 MHz, $\mathrm{CDCl}_{3}, 298 \mathrm{~K}$ ) (see SI for attribution): $\delta 9.19$ (d, $2 \mathrm{H}, J=4.9 \mathrm{~Hz}$, $\left.\mathrm{H}_{\beta p y r}\right), 9.15\left(\mathrm{~d}, 2 \mathrm{H}, J=5.0 \mathrm{~Hz}, \mathrm{H}_{\beta p y r}\right), 8.99\left(\mathrm{~s}, 2 \mathrm{H}, \mathrm{H}_{\beta p y r}\right), 8.88$ (d, $\left.2 \mathrm{H}, J=8.2 \mathrm{~Hz}, \mathrm{H}^{3}\right), 8.81\left(\mathrm{~s}, 2 \mathrm{H}, \mathrm{H}_{\beta p y r}\right), 8.60\left(\mathrm{~d}, 2 \mathrm{H}, J=8.1 \mathrm{~Hz}, \mathrm{H}^{3^{\prime}}\right)$, $8.23\left(\mathrm{~m}, 4 \mathrm{H}, \mathrm{H}^{6}\right.$ and $\left.\mathrm{H}^{6^{\prime}}\right), 7.92\left(\mathrm{~m}, 4 \mathrm{H}, \mathrm{H}^{4}\right.$ and $\left.\mathrm{H}^{4^{\prime}}\right), 7.60(\mathrm{~m}, 4 \mathrm{H}$, $\mathrm{H}^{5}$ and $\left.\mathrm{H}^{5^{\prime}}\right), 7.26\left(\mathrm{~m}, 6 \mathrm{H}, \mathrm{H}^{9^{\prime}}\right.$ and $\left.\mathrm{H}^{18}\right), 7.19\left(\mathrm{t}, 2 \mathrm{H}, J=6.5 \mathrm{~Hz}, \mathrm{H}^{9}\right)$, $7.17\left(\mathrm{~d}, 2 \mathrm{H}, J=7.6 \mathrm{~Hz}, \mathrm{H}^{19}\right), 7.06(\mathrm{~s}, 2 \mathrm{H}, \mathrm{HCONH}), 7.0(\mathrm{~d}, 4 \mathrm{H}$, $\left.J=6.8 \mathrm{~Hz}, \mathrm{H}^{17}\right), 6.79\left(\mathrm{t}, 2 \mathrm{H}, J=7.7 \mathrm{~Hz}, \mathrm{H}^{10^{\prime}}\right), 6.70(\mathrm{t}, 2 \mathrm{H}, J=7.7 \mathrm{~Hz}$, $\left.\mathrm{H}^{10}\right), 6.69\left(\mathrm{~s}, 2 \mathrm{H}, H \mathrm{CONH}^{\prime}\right), 6.63\left(\mathrm{~d}, 2 \mathrm{H}, J=7.7 \mathrm{~Hz}, \mathrm{H}^{11^{\prime}}\right), 6.50(\mathrm{~d}$, $\left.2 \mathrm{H}, J=7.6 \mathrm{~Hz}, \mathrm{H}^{11}\right), 3.88\left(\mathrm{~s}, 2 \mathrm{H}, \mathrm{H}^{13^{\prime}}\right), 2.93\left(\mathrm{~s}, 2 \mathrm{H}, \mathrm{H}^{13}\right), 1.5(\mathrm{~d}, 2 \mathrm{H}$, $\left.J^{2}=13.0 \mathrm{~Hz}, \mathrm{H}^{14 \mathrm{~A}}\right), 1.16\left(\mathrm{~m}, 2 \mathrm{H}, \mathrm{H}^{15}\right),-0.18\left(\mathrm{~d}, 2 \mathrm{H}, J^{2}=13.0 \mathrm{~Hz}\right.$, $\left.\mathrm{H}^{14 \mathrm{~B}}\right),-0.35\left(\mathrm{~d}, 2 \mathrm{H}, J^{2}=15.7 \mathrm{~Hz}, \mathrm{H}^{14 \mathrm{~A}^{\prime}}\right),-0.54(\mathrm{~d}, 6 \mathrm{H}, J=6.7 \mathrm{~Hz}$, $\left.\mathrm{H}^{16}\right),-0.73\left(\mathrm{~d}, 2 \mathrm{H}, \mathrm{J}^{2}=15.3 \mathrm{~Hz}, \mathrm{H}^{14 \mathrm{~B}^{\prime}}\right),-2.04 \mathrm{ppm}\left(\mathrm{s}, 2 \mathrm{H},-\mathrm{NH}_{2}\right) .{ }^{13} \mathrm{C}$ NMR $\left(100 \mathrm{MHz}, \mathrm{CDCl}_{3}, 298 \mathrm{~K}\right): \delta 207.05,164.68,164.61$, $144.24,140.46,139.37,138.46,134.31,133.95,133.44$, $132.59,131.79,131.32,130.92,130.79,130.56,130.04$, $128.77,128.60,128.51,127.33,126.93,125.94,124.59$, $123.97,123.53,122.05,121.90,120.70,116.16,115.76,62.38$, 55.65, 51.23, 31.73, 31.06, 29.21, 22.08, 18.08, 14.26, 11.57 ppm. UV-Vis: $\lambda_{\max }\left(\mathrm{CH}_{2} \mathrm{Cl}_{2}\right): \mathrm{nm} 423,515,587\left(\log \varepsilon_{\mathrm{M}}\right.$ 5.37, 4.16 and 2.67). IR $\left(\mathrm{CH}_{2} \mathrm{Cl}_{2}\right): \mathrm{v}=3683.1(w), 3423.5(w), 3312.4(w)$, $1711.0(w), 1683.8(w), 1605.8(w), 1581.5(w), 1523.0(w)$, $1448.1(w), 1309.7(w), 1259.3(w), 1235.9 \mathrm{~cm}^{-1}(w)$. IR (ATR): $v=3424.7(w), 3309.2(w), 1680.7(w), 1605.1(w), 1580.4(w)$, 1514.5 (w), 1443.0 (w), $1304.4(w), 1259.3(w), 1235.9 \mathrm{~cm}^{-1}$ (w). Elem. Anal. Calcd. for $\mathrm{C}_{92} \mathrm{H}_{72} \mathrm{~N}_{10} \mathrm{O}_{4}: \mathrm{C}, 79.98 ; \mathrm{H}, 5.25 ; \mathrm{N}$, 10.14. Found: $\mathrm{C}, 79.56 ; \mathrm{H}, 5.07 ; \mathrm{N}, 9.98$. ESI: $m / z=1381.5\left[\mathrm{M}^{+}\right]$.

Synthesis of Porphyrin 5. Porphyrin 2 ( $\left.0.500 \mathrm{~g}, 3.89 \cdot 10^{-4} \mathrm{~mol}\right)$, (L)-phenylalanine methyl ester hydrochloride $(0.418 \mathrm{~g}$, $\left.1.94 \cdot 10^{-4} \mathrm{~mol}\right)$, Nal $\left(0.583 \mathrm{~g}, 3.89 \cdot 10^{-3} \mathrm{~mol}\right)$ and $\mathrm{K}_{2} \mathrm{CO}_{3}(1.08 \mathrm{~g}$, $7.78 \cdot 10^{-3} \mathrm{~mol}$ ) were dissolved under argon in $450.0 \mathrm{~mL}$ of THF and $50.0 \mathrm{~mL}$ of DMF. The mixture was refluxed under stirring 
for 6 hours until the complete consumption of $\mathbf{2}$, which was monitored by TLC. Then, the solvent was evaporated to dryness and $\mathrm{CH}_{2} \mathrm{Cl}_{2}$ was added to the residue. The organic phase was extracted with $0.5 \mathrm{M} \mathrm{HCl}$ solution $(50.0 \mathrm{~mL}$ added three times), water (50.0 $\mathrm{mL}$ added three times) and then dried over $\mathrm{NaSO}_{4}$ and filtered. The filtrate was evaporated to dryness under reduced pressure and the crude purified by flash chromatography (silica gel, $15 \mu \mathrm{m}, 0.3 \% \mathrm{MeOH}$ in $\mathrm{CH}_{2} \mathrm{Cl}_{2}$ ) to obtain a dark purple solid $(0.297 \mathrm{~g}, 55 \%) .{ }^{1} \mathrm{H} \mathrm{NMR}(500 \mathrm{MHz}$, $\mathrm{CDCl}_{3}, 330 \mathrm{~K}$ ) (see SI for attribution): $\delta 8.90\left(\mathrm{~s}, 2 \mathrm{H}, \mathrm{H}_{\beta p y r}\right), 8.89$ (s, $\left.2 \mathrm{H}, \mathrm{H}_{\beta p y r}\right), 8.88$ (d, $\left.2 \mathrm{H}, J=5.14 \mathrm{~Hz}, \mathrm{H}_{\beta p y r}\right), 8.81$ (d, $2 \mathrm{H}, J=4.8$ $\mathrm{Hz}, \mathrm{H}_{\text {ppyr }}$ ), $8.77\left(\mathrm{~d}, 2 \mathrm{H}, J=8.28 \mathrm{~Hz}, \mathrm{H}^{3}\right), 8.65(\mathrm{~d}, 2 \mathrm{H}, J=8.11 \mathrm{~Hz}$, $\left.\mathrm{H}^{3^{\prime}}\right), 8.13\left(\mathrm{~d}, 2 \mathrm{H}, J=6.6 \mathrm{~Hz}, \mathrm{H}^{6}\right), 7.96\left(\mathrm{~d}, 2 \mathrm{H}, J=7.4 \mathrm{~Hz}, \mathrm{H}^{6^{\prime}}\right), 7.91$ $\left(\mathrm{t}, 2 \mathrm{H}, J=7.6 \mathrm{~Hz}, \mathrm{H}^{4}\right), 7.87\left(\mathrm{t}, 2 \mathrm{H}, J=7.5 \mathrm{~Hz}, \mathrm{H}^{4^{\prime}}\right), 7.60(\mathrm{t}, 2 \mathrm{H}, J=7.5$ $\left.\mathrm{Hz}, \mathrm{H}^{5}\right), 7.53\left(\mathrm{t}, 2 \mathrm{H}, J=7.5 \mathrm{~Hz}, \mathrm{H}^{5^{\prime}}\right), 7.21\left(\mathrm{~d}, 2 \mathrm{H}, J=8.0 \mathrm{~Hz}, \mathrm{H}^{9}\right)$, $7.18\left(\mathrm{~m}, 6 \mathrm{H}, \mathrm{H}^{19}\right.$ and $\left.\mathrm{H}^{20}\right), 7.11\left(\mathrm{~d}, 2 \mathrm{H}, J=7.7 \mathrm{~Hz}, \mathrm{H}^{9^{\prime}}\right), 7.08(\mathrm{~s}, 2 \mathrm{H}$, HCONH), $7.01\left(\mathrm{~s}, 2 \mathrm{H}, H \mathrm{CONH} \mathrm{H}^{\prime}\right), 6.71\left(\mathrm{t}, 4 \mathrm{H}, J=7.5 \mathrm{~Hz}, \mathrm{H}^{10} \mathrm{e} \mathrm{H}^{10^{\prime}}\right.$ ), $6.68\left(\mathrm{~d}, 2 \mathrm{H}, J=7.7 \mathrm{~Hz}, \mathrm{H}^{18}\right), 6.57\left(\mathrm{~d}, 2 \mathrm{H}, J=7.7 \mathrm{~Hz}, \mathrm{H}^{11^{\prime}}\right), 6.48(\mathrm{~d}$, $\left.2 \mathrm{H}, J=7.6 \mathrm{~Hz}, \mathrm{H}^{11}\right), 4.54\left(\mathrm{~s}, 2 \mathrm{H}, \mathrm{H}^{13^{\prime}}\right), 4.43\left(\mathrm{~s}, 2 \mathrm{H}, \mathrm{H}^{13}\right), 3.15(\mathrm{~s}$, $\left.6 \mathrm{H}, \mathrm{H}^{21}\right), 2.60\left(\mathrm{dd}, 2 \mathrm{H}, J=6.04, J=8.95 \mathrm{~Hz}, \mathrm{H}^{15}\right), 2.24(\mathrm{dd}, 2 \mathrm{H}$, $\left.J=9.3 \mathrm{~Hz}, J^{2}=13.6 \mathrm{~Hz}, \mathrm{H}^{16}\right), 2.06\left(\mathrm{~d}, 2 \mathrm{H}, J=14.2 \mathrm{~Hz}, \mathrm{H}^{14 \mathrm{~A}}\right), 1.68(\mathrm{~d}$, $2 \mathrm{H}, J=14.4 \mathrm{~Hz}, \mathrm{H}^{14 \mathrm{~A}^{\prime}}$ ), $1.40\left(\mathrm{dd}, 2 \mathrm{H}, J=5.7 \mathrm{~Hz}, J^{2}=13.5 \mathrm{~Hz}, \mathrm{H}^{16^{\prime}}\right.$ ), $1.08\left(\mathrm{~d}, 2 \mathrm{H}, J=14.7 \mathrm{~Hz}, \mathrm{H}^{14^{\prime} \mathrm{B}}\right), 0.93\left(\mathrm{~d}, 2 \mathrm{H}, J=15.4 \mathrm{~Hz}, \mathrm{H}^{14 \mathrm{~B}}\right),-2.31$ $\operatorname{ppm}\left(\mathrm{s}, 2 \mathrm{H},-\mathrm{NH}_{2}\right) .{ }^{13} \mathrm{C}$ NMR $\left(125 \mathrm{MHz}, \mathrm{CDCl}_{3}, 298 \mathrm{~K}\right): \delta 171.40$, $165.09,165.05,138.91,138.82,138.19,137.30,134.27$, $134.16,134.06,133.86,131.89,131.57,131.39,131.13$, $130.50,130.41,129.07,128.57,128.49,126.78,126.61$, $126.14,124.28,123.94,123.78,122.06,121.85,115.56$, 115.28, 64.01, 53.12, 52.72, 51.22, 32.52, 29.84, 14.26 ppm. UV-Vis: $\lambda_{\max }\left(\mathrm{CH}_{2} \mathrm{Cl}_{2}\right): \mathrm{nm} \mathrm{423,514}$ and $587\left(\log \varepsilon_{\mathrm{M}} 5.68,5.02\right.$ and 4.15). IR $\left(\mathrm{CH}_{2} \mathrm{Cl}_{2}\right): \mathrm{v}=3678(\mathrm{w}), 3423(\mathrm{w}), 3315(\mathrm{w}), 1736$ $(w), 1680(w), 1606(w), 1581(w), 1522(w), 1447(w), 1348$ $(w), 1308 \mathrm{~cm}^{-1}(w) . \quad$ IR (ATR): $v=3419(w), 1741(w), 1680(w)$, 1604 (w), 1580 (w), 1519 (w), 1446 (w), $1347(w), 1312 \mathrm{~cm}^{-1}$ (w). Elem. Anal. Calcd. for $\mathrm{C}_{96} \mathrm{H}_{76} \mathrm{~N}_{10} \mathrm{O}_{8}: C, 76.99 ; \mathrm{H}, 5.11 ; \mathrm{N}$, 9.35. Found: C, 76.59; H, 5.50; $N, 9.20$. ESI: $m / z=1497.6\left[\mathrm{M}^{+}\right]$.

Synthesis of complex Fe(3)OMe. In a dried $25.0 \mathrm{~mL}$ Schlenk flask, porphyrin $3\left(0.030 \mathrm{~g}, 2.10 \cdot 10^{-5} \mathrm{~mol}\right)$ and $\mathrm{FeBr}_{2}(0.045 \mathrm{~g}$, $2.10 \cdot 10^{-4} \mathrm{~mol}$ ) were dissolved in $12.0 \mathrm{~mL}$ of anhydrous THF and the resulting dark solution was refluxed for 12 hours under stirring until the complete consumption of $\mathbf{3}$, that was monitored by TLC. The solvent was evaporated to dryness under reduced pressure and the crude purified by chromatography (alumina $0.063-0.200 \mathrm{~mm}, 0.5 \% \mathrm{MeOH}$ in $\left.\mathrm{CH}_{2} \mathrm{Cl}_{2}\right)$ to obtain a dark brown solid $(0.029 \mathrm{~g}, 94 \%)$. UV-Vis: $\lambda_{\max }\left(\mathrm{CH}_{2} \mathrm{Cl}_{2}\right): \mathrm{nm} 420$ and 569 ( $\log \varepsilon_{\mathrm{M}} 5.36$ and 3.87). IR $\left(\mathrm{CH}_{2} \mathrm{Cl}_{2}\right): \mathrm{v}=3688(w), 3421(w), 2962(w), 2929(w), 2855(w)$, $1726(w), 1683(w), 1581(w), 1516(w), 1448(w), 1096(w)$, $1012 \mathrm{~cm}^{-1}(w)$. IR (ATR): $v=2962(w), 1260(w), 1101(w), 1017$ $(w), 800 \mathrm{~cm}^{-1}(\mathrm{w}) . \mathrm{ESI}: \mathrm{m} / \mathrm{z}=1552.6\left[\mathrm{M}+\mathrm{K}^{+}\right]$.

Synthesis of complex Fe(4)OMe. In a dried $25.0 \mathrm{~mL}$ Schlenk flask, porphyrin $4\left(0.030 \mathrm{~g}, 2.17 \cdot 10^{-5} \mathrm{~mol}\right)$ and $\mathrm{FeBr}_{2}(0.047 \mathrm{~g}$, $2.17 \cdot 10^{-4} \mathrm{~mol}$ ) were dissolved in $12.0 \mathrm{~mL}$ of anhydrous THF. The resulting dark solution was refluxed under stirring for 4 hours until the complete consumption of $\mathbf{4}$, that was monitored by TLC. The solvent was evaporated to dryness under reduced pressure and the crude purified by chromatography (alumina
0.063-0.200 mm, 0.3\% MeOH in $\mathrm{CH}_{2} \mathrm{Cl}_{2}$ ) to obtain a dark brown solid (0.028 g, 90\%). UV-Vis: $\lambda_{\max }\left(\mathrm{CH}_{2} \mathrm{Cl}_{2}\right): \mathrm{nm} 420$ and 578 (log $\varepsilon_{\mathrm{M}} 5.40$ and 2.75). IR $\left(\mathrm{CH}_{2} \mathrm{Cl}_{2}\right): v=3684(w), 3425(w), 3313(w)$, $1711(w), 1685(w), 1606(w), 1581(w), 1523(w), 1448(w)$, $1308(w), 1258(w), 1237 \mathrm{~cm}^{-1}(w)$. IR (ATR): $v=3424(w), 3310$ (w), $1681(w), 1606(w), 1580(w), 1516(w), 1443(w), 1305$ (w), $1260(w), 1237 \mathrm{~cm}^{-1}(w)$. Elem. Anal. Calcd. for $\mathrm{C}_{93} \mathrm{H}_{73} \mathrm{FeN}_{10} \mathrm{O}_{5}: \mathrm{C}, 76.17 ; \mathrm{H}, 5.02 ; \mathrm{N}, 9.55$. Found: $\mathrm{C}, 76.30 ; \mathrm{H}$, 5.10; N, 9.40. ESI: $m / z=1466\left[\mathrm{M}^{+}\right]$.

Synthesis of complex Fe(5)OMe. In a dried $25.0 \mathrm{~mL}$ Schlenk flask, porphyrin $5\left(0.030 \mathrm{~g}, 2.0 \cdot 10^{-5} \mathrm{~mol}\right)$ and $\mathrm{FeBr}_{2}(0.043 \mathrm{~g}$, $2.0 \cdot 10^{-4} \mathrm{~mol}$ ) were dissolved in $12.0 \mathrm{~mL}$ of anhydrous THF and the resulting dark solution was refluxed for 4 hours under stirring until the complete consumption of $\mathbf{5}$, that was monitored by TLC. The solvent was evaporated to dryness under reduced pressure and the crude purified by chromatography (alumina $0.063-0.200 \mathrm{~mm}, 0.5 \% \mathrm{MeOH}$ in $\mathrm{CH}_{2} \mathrm{Cl}_{2}$ ) to obtain a dark brown solid (0.029 g, 92\%). UV-Vis: $\lambda_{\max }\left(\mathrm{CH}_{2} \mathrm{Cl}_{2}\right): \mathrm{nm} 423$ and 584 ( $\log \varepsilon_{\mathrm{M}} 5.50$ and 3.97). IR $\left(\mathrm{CH}_{2} \mathrm{Cl}_{2}\right): v=3680(w), 3421(w), 3314(w), 1732(w), 1683(w)$, 1608 (w), 1583 (w), 1448 (w), $1350(w), 1308 \mathrm{~cm}^{-1}(w)$. IR (ATR): $v=3420(w), 1735(w), 1680(w), 1579(w), 1445(w)$, $1310 \mathrm{~cm}^{-1}(\mathrm{~W})$. ESI: $m / z=1581\left[\mathrm{M}^{+}\right]$.

General catalytic procedures. Analytical data of cyclopropanes 6 and 7 were in accordance with reported data. ${ }^{59,} 60$ The $6.8 \cdot 10^{-4} \mathrm{~mol} / \mathrm{L}$ stock solution of the catalyst was prepared by dissolving $6.8 \cdot 10^{-6} \mathrm{~mol}$ of the opportune catalyst (Fe(2)OMe, $\mathrm{Fe}(3) \mathrm{OMe}$ or $\mathrm{Fe}(4) \mathrm{OMe}$ ) in $10.0 \mathrm{~mL}$ of anhydrous toluene. The obtained solution was used for the following catalytic reactions. Method a. In a typical run, $1.0 \mathrm{~mL}$ of the stock solution was dissolved in $2.0 \mathrm{~mL}$ of anhydrous toluene. Then $\alpha$-methylstyrene and the diazo compound were added in a molar ratio catalyst/ $\alpha$-methylstyrene/diazo compound = 1:1000:1100 at the selected temperature (see Table 1). The consumption of the diazo compound was monitored by IR spectroscopy by measuring the decrease of the characteristic $\mathrm{N}_{2}$ absorbance at $\approx 2110 \mathrm{~cm}^{-1}$. The reaction was considered completed when the absorbance went below 0.03 (by using a $0.5 \mathrm{~mm}$-thickness cell). The solvent was evaporated to dryness and the residue analysed by ${ }^{1} \mathrm{H}$ NMR by using $2,4-$ dinitrotoluene as the internal standard and by HPLC by using a chiral column (DAI-CEL CHIRALCEL, IB, ${ }^{n}$ hexane/'propanol=99.75:0.25). Method $\boldsymbol{b}$. The procedure illustrated for method $a$ was repeated in the presence of activated $4 \AA$ molecular sieves. Method c. The procedure illustrated for method a was repeated using a syringe pump to add the diazo compound.

Single-Crystal X-ray Analyses. CCDC 1536861. $\left(2\left(\mathrm{C}_{96} \mathrm{H}_{76} \mathrm{~N}_{10} \mathrm{O}_{8}\right), 3\left(\mathrm{C} \mathrm{H} \mathrm{Cl}_{3}\right)\right) ; \quad M=3353.43$. D8 VENTURE Bruker AXS diffractometer, ${ }^{61}$ Mo-K $\alpha$ radiation $(\lambda=0.71073 \AA$ ), $T=150 \mathrm{~K}$; triclinic $P 1$ (I.T.\#1), $a=12.7372(10), b=$ 13.5883(12), $c=26.157(3) \AA, \alpha=82.596(3), b=76.789(3), v=$ $82.552(3)^{\circ}, V=4347.0(7) \AA^{3} . Z=1, d=1.281 \mathrm{~g} . \mathrm{cm}^{-3}, \mu=0.215$ $\mathrm{mm}^{-1}$. The structure was solved by dual-space algorithm using the SHELXT program, ${ }^{62}$ and then refined with full-matrix leastsquare methods based on $F^{2}$ (SHELXL-2014)..$^{63}$ The contribution of the disordered solvents to the calculated structure factors 
was estimated following the BYPASS algorithm, ${ }^{64}$ implemented as the SQUEEZE option in PLATON. ${ }^{65}$ A new data set, free of solvent contribution, was then used in the final refinement. All non-hydrogen atoms were refined with anisotropic atomic displacement parameters. $\mathrm{H}$ atoms were finally included in their calculated positions. A final refinement on $F^{2}$ with 36039 unique intensities and 2035 parameters converged at $\omega R\left(F^{2}\right)=$ $0.2298(R(F)=0.0825)$ for 29468 observed reflections with $I>$ $2 \sigma(I)$.

Theoretical calculations. The Gaussian09 program package ${ }^{54}$ was used for all the optimizations of the model ligands and the transition states catalysed by the corresponding iron porphyrin complexes. The starting structures were optimised in the gasphase at the B3LYP/6-31G(d) level ${ }^{55,56}$ for all the atoms but iron for which the effective core potential LanL2DZ was used. Optimisations of the iron complexes were performed on the doublet $(S=1 / 2)$ spin state, already found to be preferred in similar cases. ${ }^{41}$ Vibrational frequencies were computed at the same level of theory to define the optimised structures as minima or transition states. In all the cases, the transition states present an imaginary frequency corresponding to the forming bonds.

\section{Conclusions}

We described the synthesis and characterisation of three new chiral $C_{2}$-symmetrical porphyrin ligands, as well as their iron(III) complexes, to test them as cyclopropanation catalysts. Taking advantage of the reactivity of benzylic groups of picket $\alpha \alpha \beta \beta$ porphyrin 2 with amino functionalities, a general procedure was applied to synthesise porphyrins 3, 4 and $\mathbf{5}$. It should be noted that the intramolecular formation of two additional macrocycles was favoured with respect to intermolecular reactions between benzylic pickets of different molecules with the consequent formation of $\mathbf{3 , 4}$ and $\mathbf{5}$ in good yields. In addition, the high versatility of this synthetic approach can be exploited to obtain a larger library of chiral porphyrins.

The catalytic study confirmed that the reaction diastereoselectivity was mainly governed by the achiral portions of the totem molecule, which impose a fruitful tridimensional arrangement to the entire ligand. The presence of amino acid residues as chiral 'hats' was not effective to select an enantiomeric pathway and modest reaction enantioselectivities were achieved.

The rationalisation of catalytic data by a theoretical study was fundamental in understanding the reasons for the observed stereocontrol and more importantly in guiding the future design of other and more efficient $C_{2}$-symmetrical chiral ligands. In fact, whereas the free ligands prefer bent conformations that put the chiral moieties close to the porphyrin, the geometry they assume in the transition states of the cyclopropanation reaction is significantly different. The need to accommodate the reacting entities pushes the 'hats' away from the reaction site, so vanishing their potential effect on enantioselectivity. This suggests that ligands in which the molecular flexibility is limited enough to force 'chirality' to remain close to the porphyrin, might perform better. Their design and synthesis will be the object of future studies.

\section{Acknowledgements}

S. Le G., T. R. and B. B. thanks 'Fonds Européen de Développement Économique et Régional (FEDER)' for the financial support.

\section{Notes and references}

$1 \quad$ 1. P. Anastas and J. Warner, Green Chemistry: Theory and Practice, Oxford Univ Press, 1998.

22 B. Su, Z.-C. Cao and Z.-J. Shi, Acc. Chem. Res., 2015, 48, 886-896.

3 3. D. Intrieri, D. M. Carminati and E. Gallo, Dalton Trans., 2016, 45, 15746-15761.

4 4. W. A. Donaldson, Tetrahedron, 2001, 57, 8589-8627.

55 5. D. Y. K. Chen, R. H. Pouwer and J.-A. Richard, Chem. Soc. Rev., 2012, 41, 4631-4642.

6

6. V. Ganesh and S. Chandrasekaran, Synthesis, 2016, 48, 4347-4380.

7 7. A. Pons, T. Poisson, X. Pannecoucke, A. B. Charette and P. Jubault, Synthesis, 2016, 48, 40604071.

8 8. V. A. Rassadin and Y. Six, Tetrahedron, 2016, 72, 4701-4757.

99 9. S. Vshyvenko, J. W. Reed, T. Hudlicky and E. Piers, in Comprehensive Organic Synthesis II (Second Edition), Elsevier, Amsterdam, 2014, DOI: http://dx.doi.org/10.1016/B978-0-08-097742-3.005231, pp. 999-1076.

$1010 . \quad$ C. A. Carson and M. A. Kerr, Chem. Soc. Rev., 2009, 38, 3051-3060.

11 11. L. Mertens and R. M. Koenigs, Org. Biomol. Chem., 2016, 14, 10547-10556.

12 12. A. Ford, H. Miel, A. Ring, C. N. Slattery, A. R. Maguire and M. A. McKervey, Chem. Rev., 2015, 115, 9981-10080.

13 13. N. M. Roda, D. N. Tran, C. Battilocchio, R. Labes, R. J. Ingham, J. M. Hawkins and S. V. Ley, Org. Biomol. Chem., 2015, 13, 2550-2554.

1414 S. T. R. Müller and T. Wirth, ChemSusChem, 2015, 8, 245-250.

15 15. B. J. Deadman, S. G. Collins and A. R. Maguire, Chem. Eur. J., 2015, 21, 2298-2308.

16 16. B. Castano, E. Gallo, D. J. Cole-Hamilton, V. Dal Santo, R. Psaro and A. Caselli, Green Chemistry, 2014, 16, 3202-3209.

17 17. D. Intrieri, D. M. Carminati and E. Gallo, in Handbook of Porphyrin Science, World Scientific Publishing Company, 2016, DOI: 10.1142/9789813149588_0001, pp. 1-99.

18 18. D. Intrieri, A. Caselli and E. Gallo, Eur. J. Inorg. Chem., 2011, 5071-5081.

$1919 . \quad$ J. V. Ruppel, K. B. Fields, N. L. Snyder and X. P. Zhang, Journal, 2010, 10, 1-84. 
20. C.-Y. Zhou, V. K.-Y. Lo and C.-M. Che, Journal, 42 2012, 21, 321-376.

21. B. J. Anding and L. K. Woo, Journal, 2012, 21, 145-319.

22. Y. Wang, X. Wen, X. Cui, L. Wojtas and X. P. Zhang, J. Am. Chem. Soc., 2017, 139, 1049-1052.

23. M. Goswami, V. Lyaskovskyy, S. r. R. Domingos, W. J. Buma, S. Woutersen, O. Troeppner, I. Ivanović-Burmazović, H. Lu, X. Cui, X. P. Zhang, E. J. Reijerse, S. DeBeer, M. M. van Schooneveld, F. F. Pfaff, K. Ray and B. de Bruin, J. Am. Chem. Soc., 2015, 137, 5468-5479.

24. X. Xu, S. Zhu, X. Cui, L. Wojtas and X. P. Zhang, Angew. Chem. Int. Ed., 2013, 52, 11857-11861. 25. A. R. Reddy, F. Hao, K. Wu, C.-Y. Zhou and C.M. Che, Angew. Chem. Int. Ed., 2016, 55, 1810-1815. 26. M. Otte, P. F. Kuijpers, O. Troeppner, I. Ivanović-Burmazović, J. N. H. Reek and B. de Bruin, Chem. Eur. J., 2014, 20, 4880-4884.

27. E. Gallo, E. Rose, B. Boitrel, L. Legnani and L. Toma, Organometallics, 2014, 33, 6081-6088.

28. S. Fantauzzi, E. Gallo, E. Rose, N. Raoul, A. Caselli, S. Issa, F. Ragaini and S. Cenini, Organometallics, 2008, 27, 6143-6151.

29. A. Penoni, R. Wanke, S. Tollari, E. Gallo, D. 50

Musella, F. Ragaini, F. Demartin and S. Cenini, Eur. J. Inorg. Chem., 2003, 1452-1460.

30. A. Caselli, M. G. Buonomenna, F. de Baldironi, L. Laera, S. Fantauzzi, F. Ragaini, E. Gallo, G. Golemme, S. Cenini and E. Drioli, J. Mol. Catal. A: Chem., 2010, 317, 72-80.

31. A. Caselli, E. Gallo, F. Ragaini, F. Ricatto, G. Abbiati and S. Cenini, Inorg. Chim. Acta, 2006, 359, 2924-2932.

32. R. L. Khade, W. Fan, Y. Ling, L. Yang, E. Oldfield and Y. Zhang, Angew. Chem. Int. Ed., 2014, 53, 75747578.

33. B. Morandi, A. Dolva and E. M. Carreira, Org. Lett., 2012, 14, 2162-2163.

34. B. Morandi and E. M. Carreira, Science, 2012, 335, 1471-1474.

35. J. Kaschel, T. F. Schneider and D. B. Werz, Angew. Chem. Int. Ed., 2012, 51, 7085-7086.

36. B. Morandi and E. M. Carreira, Angew. Chem., Int. Ed., 2010, 49, 938-941.

37. R. L. Khade and Y. Zhang, J. Am. Chem. Soc., 2015, 137, 7560-7563.

38. L. A. Wessjohann, W. Brandt and T. Thiemann, Chem. Rev., 2003, 103, 1625-1648.

39. J. Chakraborty, I. Nath and F. Verpoort, Coord. Chem. Rev., 2016, 326, 135-163.

40. S. Enthaler, K. Junge and M. Beller, Angew. Chem. Int. Ed., 2008, 47, 3317-3321.

41. D. M. Carminati, D. Intrieri, A. Caselli, S. Le Gac, B. Boitrel, L. Toma, L. Legnani and E. Gallo, Chem. Eur. J., 2016, 22, 13599-13612.
42. D. Intrieri, S. Le Gac, A. Caselli, E. Rose, B. Boitrel and E. Gallo, Chem. Commun., 2014, 50, 18111813.

43. K. Karikis, E. Georgilis, G. Charalambidis, A. Petrou, O. Vakuliuk, T. Chatziioannou, I. Raptaki, S. Tsovola, I. Papakyriacou, A. Mitraki, D. T. Gryko and A. G. Coutsolelos, Chem. Eur. J., 2016, 22, 11245-11252.

44. A. K. Paul, S. C. Karunakaran, J. Joseph and D. Ramaiah, Photochem. Photobiol., 2015, 91, 1348-1355.

45. E. Galardon, P. Le Maux, A. Bondon and G. Simonneaux, Tetrahedron: Asymmetry, 1999, 10, 42034210.

46. C. Morice, P. Le Maux, G. Simonneaux and L. Toupet, J. Chem. Soc., Dalton Trans., 1998, DOI: 10.1039/A804704I, 4165-4172.

47. S. A. Dingsdag, B. C. M. Yap, N. Hunter and M. J. Crossley, Org. Biomol. Chem., 2015, 13, 98-109.

48 48. S. Meng, Z. Xu, G. Hong, L. Zhao, Z. Zhao, J. Guo, H. Ji and T. Liu, European Journal of Medicinal Chemistry, 2015, 92, 35-48.

49. V. V. Serra, A. Zamarrón, M. A. F. Faustino, M. C. I.-d. I. Cruz, A. Blázquez, J. M. M. Rodrigues, M. G. P. M. S. Neves, J. A. S. Cavaleiro, A. Juarranz and F. SanzRodríguez, Bioorg. Med. Chem., 2010, 18, 6170-6178.

50. B. Boitrel, V. Baveux-Chambenoît and P. Richard, Helv. Chim. Acta, 2004, 87, 2447-2464.

51 51. B. Boitrel and V. Baveux-Chambenoit, New J. Chem., 2003, 27, 942-947.

$5252 . \quad$ B. Boitrel, V. Baveux-Chambenoît and P. Richard, Eur. J. Inorg. Chem., 2002, 2002, 1666-1672.

53 53. A. Didier, L. Michaudet, D. Ricard, V. BaveuxChambenoît, P. Richard and B. Boitrel, Eur. J. Org. Chem., 2001, 2001, 1917-1926.

5454 54 Gaussian 09, Revision B.01, M. J. Frisch, G. W. Trucks, H. B. Schlegel, G. E. Scuseria, M. A. Robb, J. R. Cheeseman, G. Scalmani, V. Barone, B. Mennucci, G. A. Petersson, H. Nakatsuji, M. Caricato, X. Li, H. P. Hratchian, A. F. Izmaylov, J. Bloino, G. Zheng, J. L. Sonnenberg, M. Hada, M. Ehara, K. Toyota, R. Fukuda, J. Hasegawa, M. Ishida, T. Nakajima, Y. Honda, O. Kitao, H. Nakai, T. Vreven, J. A. Montgomery, Jr., J. E. Peralta, F. Ogliaro, M. Bearpark, J. J. Heyd, E. Brothers, K. N. Kudin, V. N. Staroverov, T. Keith, R. Kobayashi, J. Normand, K. Raghavachari, A. Rendell, J. C. Burant, S. S. Iyengar, J. Tomasi, M. Cossi, N. Rega, J. M. Millam, M. Klene, J. E. Knox, J. B. Cross, V. Bakken, C. Adamo, J. Jaramillo, R. Gomperts, R. E. Stratmann, O. Yazyev, A. J. Austin, R. Cammi, C. Pomelli, J. W. Ochterski, R. L. Martin, K. Morokuma, V. G. Zakrzewski, G. A. Voth, P. Salvador, J. J. Dannenberg, S. Dapprich, A. D. Daniels, O. Farkas, J. B. Foresman, J. V. Ortiz, J. Cioslowski, D. J. Fox, Gaussian, Inc., Wallingford CT, 2010.

$55 \quad 55 . \quad$ D. B. Axel, J. Chem. Phys., 1993, 98, 56485652.

56. C. Lee, W. Yang and R. G. Parr, Phys. Rev. B, 1988, 37, 785-789.

$5757 . \quad$ D. A. Sharon, D. Mallick, B. Wang and S. Shaik, J. Am. Chem. Soc., 2016, 138, 9597-9610. 

Roisnel and B. Boitrel, J. Porphyrins Phthalocyanines, 2010, 14, 412-420.

$5959 . \quad$ Y. Chen and X. P. Zhang, J. Org. Chem., 2004, 69, 2431-2435.

60 60. S. Ishikawa, R. Hudson, M. Masnadi, M. Bateman, A. Castonguay, N. Braidy, A. Moores and C.-J. Li, Tetrahedron, 2014, 70, 6162-6168.

61 61. Thanks to FEDER founds

62 62. G. Sheldrick, Acta Cryst. , 2015, A71, 3-8.

63 63. G. Sheldrick, Acta Cryst., 2015, C71, 3-8.

64 64. P. van der Sluis and A. L. Spek, Acta Cryst., 1990, A46, 194-201.

65

65. A. Spek, J. Appl. Cryst., 2003, 36, 7-13. 